\title{
Key competencies and characteristics of accommodation managers
}

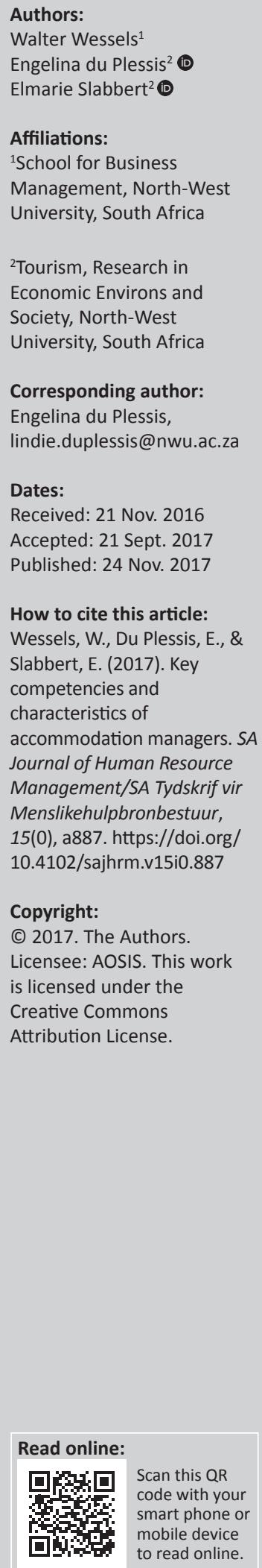

Orientation: Tourism employees are trained by various higher education institutions, yet industry still voices its concern regarding the readiness of potential employees entering the tourism industry.

Research purpose: This article aims to critically assess the key competencies and personal characteristics needed by accommodation managers in the South Africa tourism industry based on the opinions of the industry itself.

Motivation for the study: Tertiary institutions in South Africa educate potential tourism employees in a variety of skills and knowledge. However, some employers are still of the opinion that these students are not adequately prepared for the demand of the industry. Therefore, the tourism industry feels that students are not employable, which creates challenges for students, tertiary institutions and the tourism industry.

Research, design, approach and method: It was achieved by collecting 254 self-administered questionnaires from graded tourism accommodation establishments in South Africa.

Main findings: Nine key competencies needed by accommodation managers were identified and the importance of certain personal characteristics was evident. Novel to this field of research, the latter was rated more important than the nine key competencies that hold implications for training institutions and the industry.

Practical/managerial implications: The implication of the study is that accommodation managers should be trained in a different manner and higher education institutions should revise their training methods and selection strategies to address the needs of industry.

Contribution: Effective selection and training of accommodation managers will improve not only business success but also contribute to the success and growth of the tourism industry.

\section{Introduction}

South Africa relies on the tourism industry as an economic contributor (Saayman \& Geldenhuys, 2003; Tassiopoulos, 2011). It contributed 3\% to the total gross domestic product (GDP) of South Africa in 2013 and is expected to grow at a rate of 3.9\% by 2024 (World Travel \& Tourism Council [WTTC], 2014):

Tourism can be defined as an experience that begins and develops from the moment interaction takes place between tourists, job providers, government systems and communities aiming to attract, entertain, transport and accommodate tourists. (Saayman, 2009a, p. 2)

The accommodation sector is the largest sector within the tourism industry, employing 75978 people (Slabbert \& Saayman, 2003; Statistics South Africa, 2009). As the tourism sector in South Africa continues to grow, the need for accommodation expands (George, 2013).

Small, medium and micro businesses, of which accommodation establishments form a large percentage, contribute not only to employment, but also to a more stable social and political climate in South Africa (Koens \& Thomas, 2015; Rogerson, 2004; Tassiopoulos, 2014). Any business in South Africa has to ensure economic growth, and thus ensure that South Africa becomes a sustainable travel destination for tourists (Maharaj \& Balkaran, 2014). To improve sustainability and remain competitive, it is important to employ the right people on all levels of the business as they are considered key stakeholders in this industry. These employees are essential in service provision, satisfying the needs of guests, creating loyalty and positive word-of-mouth about the

Note: This article is partially based on the first author's dissertation for the degree of Magister Atrium in Tourism Management at the North-West University, South Africa, with supervisor Prof. E. du Plessis, received May 2015, available here: http://dspace.nwu.ac.za/ bitstream/handle/10394/14143/Wessels_WJ.pdf?sequence $=1$ 
business. The accommodation sector thus requires a very high service standard, essential for survival as quality service contributes to the return business (Hartman, 2011). All employees, particularly managers, are key players in the delivery of service (Lillicrap \& Cousins, 2006) and a hands-on management style contributes greatly to guest satisfaction, good service and organisational performance (Mayaka \& Akama, 2007).

Despite the important role that managers play in the service delivery process, there seems to be a lack of well-trained and educated managers in tourism industry (Jeou-Shyan, Hsuan, Chih-Hsing, Lin \& Chang-Yen, 2011). This results in poorquality experiences by guests (Kusluvan, Kusluvan, Ilhan \& Buyruk, 2010), which result in an escalating effect, thus contributing to a decrease in visitor numbers. It is the task of higher education institutions to equip future employees with key managerial competencies (Baum, 2002) to be ready for the industry.

While analysing skills and knowledge on a management level is not new, most of the managerial competency studies previously undertaken have been based largely on international case studies with reference to developed countries such as North America, Asia and Western Europe (Baum, 2007; Killen, Jugdev, Drouin \& Petit, 2011; Nolen, Conway, Farrell $\&$ Monks, 2010). The South African business environment is, however, different from these, because of its history, diversity, geography, political climate (Sewdass \& Du Toit, 2014) and education levels. Therefore, this study aims to critically assess the key competencies and personal characteristics needed by accommodation managers in the South Africa tourism industry.

\section{Literature review}

The accommodation sector is one of the primary sectors in the tourism industry (McManus, 2000) that contributes greatly to a guest's satisfaction (Davies, Taylor \& Savery, 2001). Accommodation establishments, in many cases fairly small, consist of different departments, inclusive of the front office, marketing and human resources, which all contribute to the overall guest experience (George \& Hancer, 2008; Saayman, $2009 \mathrm{~b}$ ). The nature of these establishments requires managers who can handle a variety of situations and adapt to changes on a daily basis (Baker, 2001). Managers need to face and overcome challenges that influence the business environment (Amundson, 2005). Some of these challenges include working with different cultures (Weiermair, 2000), serving guests who are increasingly demanding ( $\mathrm{O}^{\prime}$ Neill, Williams, McCarthy \& Groves, 2000) and satisfying the new type of tourist who demands to be part of the tourism experience, enhanced by human interaction (Kandampully, 2000). The new type of tourist also insists on making their own bookings and using advanced technology. They make greater demands for unique experiences, focus on their own well-being and require more privacy when staying at accommodation establishments (Lubbe, 2005; Saayman, 2009a).
Accommodation establishments are aware of these challenges and the effects that these exert on the establishment; thus, they rely on the skills and knowledge that the employees attained even before employment to assist with future direction, success and management of the challenges mentioned above (Anderson \& Vinceze, 2000). A certain set of skills and knowledge is thus expected from accommodation managers, and as critical as it is, the exact draft of these for accommodation establishment managers is unknown.

\section{Managerial skills necessary for managers in the tourism industry}

Given the service orientation of the tourism industry and the nature of the accommodation sector, managers need to be equipped with multiple skills and knowledge to make a difference in the business (Hurd, Barcekona \& Meldrum, 2008). Various studies have identified skills and knowledge needed by managers to effectively function in the hospitality environment, but the applicability and relevance of those to accommodation managers are unknown. After an extensive literature review of previous studies regarding skills and knowledge needed by managers in the tourism industry, the following were identified as recorded in Table 1.

As evident in Table 1, the first important set of skills and knowledge includes forecasting skills and knowledge. These are essential because of the extensive impact on the future development of accommodation establishments (Louw, 2011; Saayman \& Saayman, 2008). Factors such as the price of service (Perloff, 2007), transport costs (Brakke, 2005), exchange rates (Forsyth \& Dwyer, 2009), culture (Getz, 2008) and population (Hamilton, 2004) are some of the most important aspects that impact the future development of any accommodation establishment, and these can be forecast. Effective forecasting will guide all decisions in the establishment and assist in assessing the industry environment to the benefit of the establishment. It is, however, not known

TABLE 1: Skills and knowledge needed by managers in the tourism industry based on a literature review. Skills and knowledge identified Industry forecasting skills and knowledge

Strategic management skills and knowledge

Human resource management skills and knowledge

Communication skills Previous research Jeou-Shyan et al. (2011); Louw (2011); Saayman and Saayman (2008).

Cecil and Krohn (2012); Harrington and Ottenbacher (2010); Killen et al. (2011). Baum (2012); Jeou-Shyan et al. (2011); Suh, West and Shin (2012).

Mmope (2010); Theunissen and Wan Noordin (2012).

Information technology skills and knowledge

Ewan (2012); Matjila (2008.

Problem solving and crisis management skills and knowledge

Customer service skills and knowledge

Brownell (2008); Shaw (2010); Tassiopoulos (2010).

Allen (2004); Brink and Berndt (2008); Cant and Van Heerden (2008); George (2013); Kotler, Bowen \& Makens (2006); Lovelock and Wirtz (2011); Nolen et al. (2010).

Financial management skills and knowledge

Bowdin, Allen, O'Toole, Harris and McDonnell (2011); Lovemore and Brummer (2010); Sisson and Adams (2013).

Marketing and market analysis skills and knowledge

Cant, Gerber-Nel, Nel and Kotze (2008); George (2013); Tassiopoulos (2010).

Note: Please see the full reference list of the article, Wessels, W., Du Plessis, E., \& Slabbert E. (2017). Key competencies and characteristics of accommodation managers. SA Journal of Human Resource Management/SA Tydskrif vir Menslikehulpbronbestuur, 15(0), a887. https://doi.org/10.4102/sajhrm.v15i0.887, for more information. 
whether this set of skills and knowledge is important to managers of smaller accommodation establishments.

Because of the intense focus on the daily operations of accommodation establishments, some managers might lose track of the strategic direction of the business. However, the capital and labour-intensive aspects of the accommodation industry (Harrington \& Ottenbacher, 2010) force accommodation managers to set future goals (Jeou-Shyan et al., 2011) and make instant decisions that have long-term implications (Connolly \& McGing, 2006). These studies emphasise the importance of strategic management skills and knowledge for managers, which might also apply to the set of skills and knowledge needed by accommodation managers.

Service in the accommodation sector relies on good human resources (Hartman, 2011; Haynes \& Fryer, 2000). The ability of managers to effectively direct employees in knowing what is expected of them and delivering quality service is one of the core management competencies (Tsaur \& Lin, 2003). Good human resource management also contributes to a decrease in the turnover rate of employees in the accommodation sector (Baum, 2012).

Communication skills are essential to all spheres of the establishment and various problems can arise from poor communication. Managers must display the ability not only to communicate internally with employees, but also to facilitate the external flow of communication with new and existing guests (Bang, 2004; Brown, 2001). Within the service environment, managers must be able to speak fluently directly to guests (Johanson, Ghiselli, Shea \& Roberts, 2010). This skill is essential regardless of the department or level of management, according to Bobanovic and Grzinic (2011). Saayman (2009b) identified communication barriers, inclusive of failure to analyse the needs of the receiver as well as poor listening and feedback from management, as service success influencers. These barriers can be overcome by managers if they are able to communicate using various communication channels to ensure that the right message is conveyed and received by all parties influenced by the conveyed message (Ewing, 2007).

According to Ewan (2012), information technology enhances communication channels but there is still a lack of research on the importance and impact of information technology on communication amongst role-players in the accommodation industry. Information technology is developing at a rapid rate and the tourism industry is known for the utilisation of online programmes and mechanisms as part of the management of accommodation establishments. Information technology not only enables fast and flexible operation (Posavec, 2008), but also allows for easy access to a large amount of stored data influencing the service encounter between guest and establishment (Stamboulis \& Skayannis, 2003). Implementing and utilising the correct information technology is therefore vital for accommodation establishments (Hudson \& Gilbert, 2006; Sun \& Howard, 2004) and managers must master information technology in order to ease operations.
Solving problems and being able to manage any crisis are essential skills for managers (Brownell, 2008; Richie, 2005), especially because this industry is about people. Kay and Russette (2000, p. 53) state that managers must ensure a winwin resolution approach for both the organisation and the guest. The ability of managers to solve problems will affect service provision of an accommodation establishment (Connolly \& McGing, 2006) as well as the return rate of guests. The creation of an internal service culture, focusing on serving and satisfying guest needs (Kotler et al., 2006), might minimise problems. No accommodation establishment operates without encountering problems, which may include aspects such as billing errors, service catastrophes, unresponsiveness from employees and having limited product knowledge (Lovelock \& Wirtz, 2011). These situations occur unexpectedly and the manager must demonstrate his or her ability to solve these situations.

Service is the foundation of the accommodation sector (Chathoth et al., 2014). Ensuring outstanding service provision is very costly for accommodation establishments and must be well managed (George, 2013). Rajaratnam, Munikrishnan, Sharif and Vikneswaran (2014) found that consumers who are satisfied with the service received will influence the image of the accommodation establishment positively through wordof-mouth. During the past 10 years, service quality has received the needed attention by academic institutions and hospitality practitioners (Dhar, 2015). The realisation of this led to action plans being put in place in order to minimise negative service experiences and maximise effective customer experiences (Allen, 2004) so as to contribute to positive financial prospects for the accommodation establishment (Burgess, 2007). Clearly, this is a critical aspect that needs to be managed.

Financial management, in the case of smaller accommodation establishments, mostly consists of monitoring the overall financial practice of an organisation (Lovemore \& Brummer, 2010) and comparing spending patterns within a set budget (Bennet, Dunne \& Carre, 2000). Even though many accommodation establishments have admitted that they outsourced their financial accounting function, it is no longer always possible because of the complexity and variety of all the internal departments and management control requirements (Burgess, 2007). Financial managers face certain challenges daily, which include gaining access to capital and managing the cost of employee turnover (Patiar \& Mia, 2009). According to Tassiopoulos (2010), successful financial management and projection can be ensured only if a manager possesses the skill to calculate and implement good financial practice.

Lastly, various authors, as evident in Table 1, have emphasised marketing as an essential skill for accommodation managers (George, 2013; Kotler et al., 2006; Slabbert \& Saayman, 2003). It is not about mass marketing anymore, it is about building long-term relationships with customers (Saayman, 2009a) and getting to know their needs. Marketing is changing on a daily basis and the electronic environment has created 
exciting opportunities for managers to effectively reach their target markets. Effective marketing can assist in creating a competitive advantage, which is much needed in the accommodation sector where high levels of competition are evident. Understanding and utilising the correct marketing tools remain important (Cant et al., 2008).

\section{Personal characteristics necessary for managers in the tourism industry}

In addition to these skills and this knowledge, various sources have emphasised the importance of certain personal characteristics (Leiper, 2004; Page, 2007; Patiar \& Mia, 2009; Sternberg \& Zhang, 2000). According to Page (2007), a manager must display an investigative personality, while Patiar and Mia (2009) found that managers must display trust, provide inspirational motivation and promote intellectual stimulation amongst co-employees. Kay and Russette (2000) as well as Suh et al. (2012) identified that accommodation managers must be able to provide effective feedback to employees regarding their work performance, promote hard work, manage conflict and promote integrity in the workplace. Within the accommodation sector, managers must be able to act as mentors for employees (Leiper, 2004) and be able to take employee feedback into consideration to ensure personal development (Sternberg \& Zhang, 2000).

With the accommodation sector showing continuous growth (McManus, 2000), Saayman (2009b) identified the ability to adapt in such an environment as an important characteristic for accommodation managers. However, to adapt in a changing environment brings about challenges for employees; therefore, accommodation managers must possess the ability to promote training opportunities to overcome the barriers to change (Hough \& White, 2001).

It is clear that a challenging and ever changing external environment necessitates that managers possess a variety of skills and knowledge, enhancing certain personal characteristics enabling them to successfully manage an accommodation establishment. Even with this knowledge, a gap appears to exist between the offering of tourism higher education programmes and the needs of the tourism industry (Zehrer \& Mössenlechner, 2009). This is supported by Swanson and Holton (2009) in studies that revealed that employees are not supplying the industry with the necessary skills and knowledge. Higher education institutions need updated insight from industry regarding these skills and knowledge in order to adapt education programmes where necessary and to present applicable programmes. This will directly contribute to the growth of the tourism industry and the employability of graduates. The question addressed by this article therefore remains: What are the key competencies needed by accommodation managers in the South African tourism industry?

\section{Research design}

The research design for this study was twofold: firstly, a descriptive research design was chosen to describe the profile of the respondents, while, secondly, exploratory factor analyses were performed to investigate the research question. The research method used is explained below.

\section{Research method Population and sampling}

The target population consisted of tourism product managers on different management levels within the accommodation sector inclusive of all nine provinces in South Africa. The TGCSA's database, which assigns star grading to participants after assessment, was used as the sample frame for this study. The TGCSA has been in operation for the past 13 years and is a recognised quality assurance body for the accommodation sector, consisting of hotels, guesthouses, self-catering units, caravan and camping parks. The TGCSA is thus a very important role-player within the accommodation sector (TGCSA, 2013). The TGCSA grades on five levels ranging from one star status to five star status, where one star grading indicates basic room options and facilities and five star grading indicates luxury accommodation with a diverse range of facilities available to guests (TGCSA, 2013).

TGCSA had 5400 graded accommodation establishments registered with the organisation in the nine provinces of South Africa during 2014 (TGCSA, 2013) which served as the population for this research. The list of these establishments is public domain, and thus it was extracted from the website of TGCSA. From the complete list of graded establishments, stratification was firstly done by means of province and secondly the establishments were ordered alphabetical which resulted in a specific number of establishments per province.

According to Krejcie and Morgan (1970), a population size $(N)$ of 5400, as provided by TGCSA, is represented by a sample size $(s)$ of 360 . To reach the representative sample of 360 , the number of expected establishments was proportionally calculated per province (one per establishment). Simple random sampling was then applied where every 15th establishment on the list was selected from each provincial list to participate in the survey. If any of the pre-selected respondents declined the request to participate in the research, the next respondent on the list was chosen (Berndt \& Petzer, 2011). In certain cases, a higher number of establishments participated because these had more than one manager.

Self-administered questionnaires were distributed over a period of 8 weeks (07 July 2104 - 09 September 2014). After each electronic questionnaire was sent out, a notification stating that the questionnaire had been received was sent back to the sender and a follow-up email was sent after every 5 days in order to ensure that the questionnaire was completed and received back in the allocated time.

A total of 360 (Table 2) questionnaires were distributed of which 254 completed questionnaires were returned by the participants in all nine provinces, resulting in a $70 \%$ response rate. 
TABLE 2: Population $(N)$, expected sample size $(s)$ and actual sample size $(S)$.

\begin{tabular}{lccc}
\hline Province & $\begin{array}{c}\text { Number of graded } \\
\text { establishments }(\boldsymbol{N})\end{array}$ & $\begin{array}{c}\text { Expected sample size } \\
(\boldsymbol{s}) \text { of total managerial } \\
\text { employees }\end{array}$ & $\begin{array}{c}\text { Actual sample size }(\boldsymbol{S}) \\
\text { total of managerial } \\
\text { employees }\end{array}$ \\
\hline Eastern Cape & 693 & 47 & 22 \\
Free State & 123 & 7 & 17 \\
Gauteng & 801 & 54 & 32 \\
KwaZulu-Natal & 747 & 50 & 37 \\
Limpopo & 264 & 18 & 31 \\
Mpumalanga & 289 & 18 & 35 \\
North-West & 185 & 11 & 15 \\
Northern Cape & 199 & 14 & 16 \\
Western Cape & 2099 & 141 & 49 \\
\hline Total(s) & $\mathbf{5 4 0 0}$ & $\mathbf{3 6 0}$ & $\mathbf{2 5 4}$ \\
\hline
\end{tabular}

\section{Data collection methods}

The development of a self-administered questionnaire was based on work carried out by various researchers (Cecil \& Krohn, 2012; Nolen et al., 2010; Sisson \& Adams, 2013; Suh et al., 2012); however, it has been used in its current format for the first time. The questionnaire consisted of two sections: demographic information of respondents (consisting of open and closed ended questions related to age and qualification level of each respondent) and characteristics and managerial competencies of an effective manager (consisting of a 5-point Likert scale where 1 was considered the least important characteristic and/or key competency and 5 was considered the most important characteristic and/or key competency of accommodation managers).

\section{Data analysis}

Descriptive statistics (profile of respondents) and factor analyses (characteristics and key competencies) were used to interpret the collected data. The data were processed by making use of SPSS $^{\odot}$ (Statistical Package for Social Sciences; Version 21.0, 2011). The exploratory factor analyses were performed to determine the underlying factors of managerial competencies and characteristics in the accommodation sector. The exploratory factor analyses attempt to produce a smaller number of linear combinations of the original variables in a manner that captures most of the variability in the pattern of correlations (Pallant, 2010).

\section{Results}

The results are reported in two sections: firstly, the profile of the respondents in the study is discussed and depicted in Table 3, whereas, secondly, the key competencies and characteristics are analysed and recorded in Table 4.

\section{Profile of the respondents}

In Table 3 , it is evident that $26 \%$ of the respondents are either between 21 and 32 years of age or 65 years and older. Thirtyfour per cent of all respondents had obtained a bachelor's degree at a university (49\%) with $16 \%$ of respondents who had not studied towards a higher qualification of any sort. The majority of the respondents hold top management positions (64\%) with $22 \%$ in middle management and $14 \%$ in entry-level management positions. The results also indicated
TABLE 3: Profile of the respondents.

\begin{tabular}{|c|c|c|}
\hline Variable & Category & Percentage \\
\hline \multirow[t]{5}{*}{ Age } & $21-32$ years & 26 \\
\hline & $33-43$ years & 14 \\
\hline & $44-54$ years & 18 \\
\hline & $55-64$ years & 16 \\
\hline & 65 years and more & 26 \\
\hline \multirow{8}{*}{$\begin{array}{l}\text { Department of } \\
\text { employment in the } \\
\text { establishment }\end{array}$} & Overall operations & 49 \\
\hline & Front Office Department & 9 \\
\hline & Food and Beverage Department & 8 \\
\hline & Financial Department & 5 \\
\hline & Human Resource Department & 2 \\
\hline & Owner and manager & 10 \\
\hline & General manager & 9 \\
\hline & Other & 8 \\
\hline \multirow{3}{*}{$\begin{array}{l}\text { Duration of employment } \\
\text { in current position }\end{array}$} & $0-5$ years & 62 \\
\hline & $6-10$ years & 21 \\
\hline & 11 years and more & 17 \\
\hline \multirow[t]{8}{*}{ Level of education } & High School & 16 \\
\hline & Certificate & 3 \\
\hline & Diploma & 33 \\
\hline & Bachelor's Degree & 34 \\
\hline & Honours Degree & 11 \\
\hline & Master's Degree & 1 \\
\hline & Doctorate Degree & 1 \\
\hline & MBA & 1 \\
\hline \multirow{3}{*}{$\begin{array}{l}\text { Current management } \\
\text { level }\end{array}$} & Top management & 64 \\
\hline & Middle management & 22 \\
\hline & Entry-level management & 14 \\
\hline \multirow{5}{*}{$\begin{array}{l}\text { Type of education } \\
\text { establishments where } \\
\text { respondents studied }\end{array}$} & University & 49 \\
\hline & College & 20 \\
\hline & Hotel School & 5 \\
\hline & Other & 8 \\
\hline & None & 18 \\
\hline
\end{tabular}

that the respondents have been employed for less than 5 years in their current position.

\section{Key competencies and personal characteristics of an accommodation manager}

Using the principal component analysis extraction method, the exploratory factor analyses for each skills and knowledge set revealed one factor per set. The Bartlett's test of Sphericity $(p \leq 0.000)$ was used to test for homoscedasticity (homogeneity of variances) and was verified in all cases. The Kaiser-MeyerOlkin (KMO) measure of sampling adequacy can be viewed as highly reliable because the KMO range is between 0.832 and 0.945 (Pallant, 2010), indicating the adequacy of the data for factor analysis. In all cases, more than $63 \%$ of the variance was explained, which is highly acceptable (Pallant, 2010). Factor loadings higher than 0.4 were considered as adequate because of the exploratory nature of the analyses (Pallant, 2010). The Cronbach's $\alpha$ s were well above the expected 0.7 (ranging between 0.891 and 0.969), which indicates a high reliability and internal consistency of these factors (Pallant, 2010, p. 249) (see Table 4). This resulted in 10 factors identified in this study.

The results indicated that within each factor, there were key competencies that had to be displayed by accommodation managers as discussed below. 
TABLE 4: Summative results of the exploratory factor analyses.

\begin{tabular}{ll}
\hline Factors & $\begin{array}{l}\text { Aspects measured in each factor } \\
\text { An accommodation manager should be or able to be: }\end{array}$ \\
\hline $\begin{array}{l}\text { Factor 1: } \\
\text { Personal characteristics (20 aspects) }\end{array}$ & $\begin{array}{l}\text { Trustworthy, intelligent, a planner, an evaluator, responsible, a } \\
\text { decision-maker, resourceful, productive, sensitive, a good } \\
\text { listener and creative }\end{array}$ \\
& \\
& $\begin{array}{l}\text { Predict future developments that will influence expansions of } \\
\text { the accommodation establishment, predict future human } \\
\text { resource development and capacity building, predict future } \\
\text { changes in consumer behaviour, predict any risks that have a } \\
\text { direct influence on the accommodation establishment, predict } \\
\text { accommodation preference, predict the effect of increased } \\
\text { operational costs and predict competitive prices for } \\
\text { accommodation establishment }\end{array}$ \\
\hline (10 aspects)
\end{tabular}

Factor 3:

Human resource management skills (17)
Strategic management skills (14)

Formulate strategic plans for an accommodation establishment, conduct an environmental analysis, formulate internal policies, practice strategic control, manage change within the accommodation establishment, analyse the external environment and plan effective resource application within the accommodation establishment

Create opportunities for career development, provide training opportunities, motivate employees, provide feedback on employee performance, communicate all management strategies to employees, match employees with available positions, facilitate teamwork, manage the effects of seasonal employees on an accommodation establishment, plan and implement focused human resources strategies, practice successful performance evaluation, influence the service behaviour of employees and determine the factors that contribute to employee turnover

Factor 5:

Problem solving and crisis

management skills (8)

Make informed decisions, solve daily problems, identify challenges and implement new strategies to reactively solve these problems, think critically, act professionally in different situations 
TABLE 4 (Continues...): Summative results of the exploratory factor analyses.

\begin{tabular}{|c|c|c|c|}
\hline Factors & $\begin{array}{l}\text { Aspects measured in each factor } \\
\text { An accommodation manager should be or able to be: }\end{array}$ & Factorability information & Statistical value \\
\hline & & Mean value & 3.72 \\
\hline & & Inter-item correlation & 0.703 \\
\hline & & Rank amongst factors & 4 \\
\hline \multirow{7}{*}{$\begin{array}{l}\text { Factor 10: } \\
\text { Marketing skills (7) }\end{array}$} & \multirow{7}{*}{$\begin{array}{l}\text { Conduct market research, identify the market by means of } \\
\text { market segmentation, compile a marketing plan, interpret } \\
\text { marketing research and findings and launch and manage a } \\
\text { marketing campaign }\end{array}$} & KMO & 0.912 \\
\hline & & Percentage of variance explained & 80.77 \\
\hline & & Cronbach's $\alpha(\mathrm{CA})$ & 0.960 \\
\hline & & Range of factor loadings & $0.769-0.849$ \\
\hline & & Mean value & 3.54 \\
\hline & & Inter-item correlation & 0.775 \\
\hline & & Rank amongst factors & 10 \\
\hline
\end{tabular}

\section{Factor 1: Personal characteristics}

The results indicated that the first factor, labelled personal characteristics, which had a mean value of 4.11 and a Cronbach's $\alpha$ of 0.966 , is the most important factor amongst the 10 identified factors. The top three characteristics to be displayed by an effective accommodation manager include trustworthiness $(M=4.52 ; \mathrm{SD}= \pm 0.735)$, responsibility $(M=4.39 ; \mathrm{SD}= \pm 0.799)$ and self-motivation $(M=4.26$; $\mathrm{SD}= \pm 0.773)$. Being sensitive was rated as the least important characteristic $(M=3.82 ; \mathrm{SD}= \pm 0.957)$. This finding supports the results of similar studies that indicated the importance of certain characteristics in a management position (Baum, 2007; Nieuwenhuizen \& Rossouw, 2012; Patiar \& Mia, 2009; Thekiso, 2011); however, the extent of its importance in comparison to management competencies is novel on a management level in this industry. According to Cronje, Du Toit, Motlatla and Marais (2006), personality characteristics influence job performance; therefore, it should play a role in the selection of students applying for tourism management programmes in higher education institutions. It is evident that certain personality characteristics add significant value to the task of managers in the accommodation sector in the same vein as accountants need to be focused on detail and nurses need to be caring. To a certain extent, these characteristics cannot be trained for and can be considered as inherently part of a person (Horng, Tsai, Yang, Lui \& Hu, 2016; Leung \& Law, 2010). To become a manager in the accommodation sector requires a certain set of characteristics that should play a role in selection and admission processes. More than that during job interviews, a number of questions directly relate to personality characteristics and thus there is value in taking cognisance of this as part of training.

\section{Factor 2: Forecasting skills}

The forecasting skills factor ranked eighth most important amongst the set of skills and knowledge with a mean value of 3.59 and a Cronbach's $\alpha$ of 0.935 . The most important forecasting skills include the identification of the effect of increased operational costs $(M=3.74 ; \mathrm{SD}= \pm 0.866)$, risk prediction $(M=3.72 ; \mathrm{SD}= \pm 0.850)$ followed by the ability of a manager to predict the effect of seasonality on the accommodation establishment $(M=3.71$; SD $= \pm 0.892)$, a unique attribute of the tourism industry. In a study conducted by Louw (2011), it was concluded that managers in accommodation establishments must be able to predict future developments in order to successfully interpret tourist behaviour and consumer demands. Given the growth of the tourism industry in South Africa, the change in source markets and the development of domestic markets (WTTC, 2014), management needs this skill to grow the organisation. Notwithstanding the importance of forecasting skills in the literature, this ability was not amongst the top three management skills identified by respondents.

\section{Factor 3: Strategic management skills}

The strategic management skills factor, with a mean value of 3.56 and a Cronbach's $\alpha$ of 0.955 , ranked the ninth most important factor. The important aspects in this factor included the ability of managers to react swiftly to changing external environments $(M=3.73 ; \mathrm{SD}= \pm 0.778)$, their ability to manage internal change $(M=3.69 ; \mathrm{SD}= \pm 0.818)$ and their ability to formulate goals $(M=3.66$; $\mathrm{SD}= \pm 0.801)$. Even though the importance of strategic management is evident in various studies, it was not considered critical in this study. Saayman (2009b) states that strategic management consists of more than just a vision and mission; it includes situational analysis that includes all aspects of the external environment, the formulation of strategic plans for an establishment to survive during any change in the external environment, the ability to implement the strategic plans and to ensure that strategic control is practised regarding the strategies implemented. Jeou-Shyan et al. (2011) state that a manager must be able to form goals and evaluate the applicability of these to decisions. Mason (2007) stated that strategic management skills are important for accommodation managers, enabling them to create a stable internal environment, especially in an ever changing external environment. In the case of this study, either the respondents do not consider strategic management important for the accommodation establishments per se or they function on a more short-term management level, and do not realise the value of strategic management skills.

\section{Factor 4: Human resource skills}

This factor was ranked as the sixth $(M=3.64)$ most important factor for this study. According to Tsaur and Lin (2003), service orientation organisations must realise the important role of human resource management. The results in this study correlate with findings in the literature. The key competencies evident in the human resources management factor $(M=3.64)$, with a Cronbach's $\alpha$ of 0.969 , include a 
manager's ability to motivate employees $(M=3.85 ; \mathrm{SD}= \pm$ $0.817)$, facilitate teamwork $(M=3.81 ; \mathrm{SD}= \pm 0.794)$ and to facilitate problem solving amongst employees $(M=3.81$; $\mathrm{SD}= \pm 0.813$ ). Building a positive relationship between management and the employees is of great importance (Kusluvan et al., 2010). It becomes even more important to invest in employees to ensure an effective team working at the establishment in order to minimise staff-turnover and optimise a constructive working environment (Spowart, 2011).

\section{Factor 5: Problem solving and crisis management}

This factor $(M=3.85)$ with a Cronbach's $\alpha$ of 0.961 indicated that the key competencies for the factor problem solving and crisis management consisted of the ability of managers to act professionally in different situations $(M=3.97$; $\mathrm{SD}= \pm 0.868)$, followed by the ability to practise effective crisis management $(M=3.90 ; \mathrm{SD}= \pm 0.854)$. The results also indicated that it is important for managers to lead inexperienced employees within the accommodation establishment $(M=3.86$; $\mathrm{SD}= \pm 0.775)$. This was the third most important factor and supports Brownell (2008, p. 138) who states that hospitality managers must implement new strategies in order to successfully solve everyday problems. These skills are essential for the rapidly changing environment that the accommodation sector faces (Middleton, 2002).

\section{Factor 6: Communication skills}

The communication skills factor, ranked as the fifth factor, calculated a mean value of 3.68 and a Cronbach's $\alpha$ of 0.946 . Good communication skills are dependent on effective interaction with employees $(M=3.83 ; \mathrm{SD}= \pm 0.758)$, managers' ability to communicate on all management levels $(M=3.78$; $\mathrm{SD}= \pm 0.764)$ and their ability to communicate in English $(M=3.76 ; \mathrm{SD}= \pm 0.858)$. This correlates with previous research which found that managers must be able to construct their message very carefully as this can be a great barrier if employees misinterpret the message provided (Huebsch, 1986). Mmope (2010) adds that managers must be able to communicate vertically, laterally and diagonally. Clearly, effective training is critical to improve and support managers' communication abilities.

\section{Factor 7: Information technology skills}

Key competencies in the information technology factor $(M=3.60)$ with a Cronbach's $\alpha$ of 0.891 included managers' ability to effectively use social media platforms to communicate vital information to guests $(M=3.71 ; \mathrm{SD}= \pm 0.847)$ as the most important aspect. This was followed by the ability to use different technologies within the accommodation establishment $(M=3.70 ; \mathrm{SD}= \pm 0.757)$ as well as the ability to operate MS Office $(M=3.68 ; \mathrm{SD}= \pm 0.850)$. This factor ranked seventh amongst the 10 factors identified. A study conducted by Ewan $(2012$, p. 1) found that a very limited understanding of the real effect that information technology has on an organisation is still prevalent amongst accommodation managers, as was the case in the current study. Making use of information technology can act as a cost saver, allowing small accommodation establishments to play in the bigger industry (Hudson \& Gilbert, 2006). The application of information technology to the business environment consequently becomes more and more important.

\section{Factor 8: Customer service skills}

As indicated in the literature, customer service skills were rated as highly important (second most important; $M=3.90$; $\alpha=0.949$ ). The main contributors to this factor were managers' ability to build customer relationships $(M=3.98 ; \mathrm{SD}= \pm 0.833)$, providing sustainable customer satisfaction $(M=3.98$; $\mathrm{SD}= \pm 0.845)$ and developing a service culture amongst employees $(M=3.96 ; \mathrm{SD}= \pm 0.847)$. These findings support Kotler et al. (2006) who stated that organisations offering a service must develop an in-house service culture, and that this development starts with top management. Allen (2004) adds that personal relationships can be built between the organisation and the guest, through accommodation, and service needs satisfaction. These aspects are very important because excellent customer service contributes to a customer returning to an accommodation establishment in future (Hartman, 2011).

\section{Factor 9: Financial management skills}

Financial management skills remain a critical aspect, even in accommodation establishments of different sizes. This factor was considered to be the fourth most important factor $(M=3.72$; $\alpha=0.955)$. Managers must be able to monitor all financial activities of the accommodation establishment $(M=3.89$; $\mathrm{SD}= \pm 0.829$ ), be able to determine the right price for products and services $(M=3.84 ; \mathrm{SD}= \pm 0.833)$ and construct and develop a budget within an establishment $(M=3.80 ; \mathrm{SD}= \pm 0.871)$. Lamminmaki (2008) notes that small, medium and micro organisations (SMME), under which the accommodation sector falls, tend to experience financial challenges; therefore, these competencies are extremely important for successful business management (Bowdin et al., 2011).

\section{Factor 10: Marketing skills}

The marketing skills factor $(M=3.54 ; \alpha=0.960)$ was considered to be the least important skill for managers. This factor included the knowledge of compiling a business plan $(M=3.61 ; \mathrm{SD}= \pm 0.800)$, the ability to determine the return on investment of marketing campaigns $(M=3.60$; $\mathrm{SD}= \pm 0.816)$ and launching and managing a marketing campaign $(M=3.58 ; \mathrm{SD}= \pm 0.813)$. This differs from the literature where George (2013, p. 14) states that marketing skills are vital, especially for small accommodation establishments, in order to survive in the current competitive environment.

In Table 4, it is evident that the top three skills and characteristics included personal characteristics $(M=4.11)$ : customer service skills $(M=3.90)$, problem solving and crisis management skills $(M=3.85)$. Although all the identified skills and knowledge should be taught at higher education institutions, it is clear where the specific focus should fall. 


\section{Discussion}

This research supports various studies regarding important management skills needed in the tourism industry. The focus on the South African accommodation sector makes the results very focused and unique in their identification and ranking of 10 key managerial competencies and personality characteristics. The findings led to the following four implications.

Firstly, the most significant finding of this study was that the aspiration to be an accommodation manager requires certain personal characteristics. This is something that cannot be taught or trained: it is inherently part of one's personality. This finding significantly changes the way higher education institutions select students for tourism management programmes. It is not only about grade 12 marks, but also about personality. Now, it is thus more than ever necessary for students to undergo aptitude and personality tests before entering education institutions and the industry to fit the profile of tourism accommodation managers.

Secondly, it was found that most participating managers were either fairly young or close to retirement and they hold either a diploma or a degree. This emphasises the importance of developing and presenting tailor-made management programmes to the graduates who will ensure that more of the latter enter and remain in the industry. The notion of being an all-rounder was also evident, especially in the accommodation sector. This study highlights where the focus should be placed in education programmes that will support the training of the all-rounder concept of a manager.

Thirdly, it was found that the industry holds high expectations of its managers. These managers should immediately deliver services as expected by the industry. The more that higher education institutions can equip students with the necessary skills and knowledge, the easier it will be to access the industry, the better these students will be prepared for the challenges and the longer they will stay in the industry. Training programmes that promote continuous learning while working in the industry should be supported.

Fourthly, the importance of customer service, problem solving and crisis management and financial management were all evident. Although most of the competencies are important, these three will mainly contribute to the success of managers and ultimately of the establishment. Again, the entry requirements to higher education institutions should address this finding because management programmes should require mathematics at entry level, and the structure of the programme should practise and emphasise customer service and solving problems. Students should be exposed to real-life scenarios where they can practise these skills and be better prepared for the industry. Programmes not currently offering work-integrated learning should consider the inclusion thereof but also plan carefully the content of these learning programmes. Training institutions can even consider setting up tourism and hospitality labs where these skills can be practised and assessed on a continuous basis. These three are therefore not only about knowledge, but also include a practical component to be practised prior to employment.

\section{Conclusion}

The aim of the article was to critically assess the key competencies and personal characteristics needed by accommodation managers in the South African tourism industry. Two-hundred and fifty-four respondents from graded accommodation establishments responded to questionnaires on this important topic. These respondents were seemingly well qualified, have worked in industry between 0 and 5 years and are responsible for overall operations on various management levels. The factor analyses revealed $10 \mathrm{key}$ managerial competencies and certain personal characteristics to be important. Amongst the 10 factors, personal characteristics were found to be the most important factor that affects the admission requirements for students to be admitted to higher education institutions. The accommodation sector requires specific personality characteristics to fit in this sector. The importance of customer service skills, problem solving skills and financial management skills is also evident. Higher education institutions should re-assess their current programmes to determine whether these topics have been extensively covered in training and whether this addresses the needs of industry currently. With that being said, it was also clear that being an all-rounder manager in the accommodation sector gives one the edge as a manager in this sector. Based on these scientific research findings, managerial training programmes in tourism management can be adapted for the first time in South Africa. This study contributes significantly to both the accommodation sector and higher education institutions in South Africa offering tourism management programmes where significant and creative adjustments and alternative training methods might be needed. For future research, this measuring instrument may be used in other sectors of the tourism industry to determine similarities and differences between the sectors. This will exert a significant influence on the development of training programmes for specific sectors.

\section{Acknowledgements}

The authors would like to acknowledge and thank the tourism industry for participating in the study and providing insightful responses.

\section{Competing interests}

The authors declare that they have no financial or personal relationships that may have inappropriately influenced them in writing this article.

\section{Authors' contributions}

W.W. conducted the research for his master's degree and therefore wrote the concept paper. E.d.P. was supervisor of this study and E.S. was the co-supervisor. Both these supervisors assisted in writing the final manuscript. 


\section{References}

Allen, J. (2004). Marketing your event planning business: A creative approach to gaining the competitive advantage. Ontario: John Wiley \& Sons Canada Ltd.

Amundson, N. (2005). The potential impact of global changes in work for career theory and practice. International Journal for Educational and Vocational Guidance, 5(2), 91-99. https://doi.org/10.1007/s10775-005-8787-0

Anderson, C.H., \& Vinceze, J.W. (2000). Strategic marketing management: Meeting the global challenge. Boston, MA: Houghton Mimin Company.

Baker, T. (2001). Customer-focused organisations: Challenges for managers, workers and HR practitioners. Journal of Management Development, 21(4), 306-314. https://doi.org/10.1108/02621710210423892

Bang, S.J. (2004). The form of the sermon and effective communication: A homiletical study. Unpublished doctoral dissertation, North-West University, Potchefstroom.

Baum, T. (2002). Skills and training for the hospitality sector: A review of issues. Journal of Vocational Education and Training, 54(3), 343-364. https://doi. org/10.1080/13636820200200204

Baum, T. (2007). Skills and hospitality sector in a transition economy: The case of fron office employment in Kyrgyzstan. Asian Pacific Journal of Tourism Research, 12(2) 91-102. https://doi.org/10.1080/10941660701243315

Baum, T. (2012). Human resource management in tourism: A small island perspective. International Journal of Culture, Tourism and Hospitality Research, 6(2), 124-132. https://doi.org/10.1108/17506181211233054

Bennet, N., Dunne, E., \& Carre, C. (2000). Skills development in higher education and employment. Buckingham: SHRE and Open University Press.

Berndt, A., \& Petzer, D. (2011). Marketing research. Cape Town: Pearson Education South Africa (Pty) Ltd.

Bobanovic, M., \& Grzinic, J. (2011). The importance of English language skills in the tourism sector: A comparative study of students/employees perspective in Croatia. Almatourism, 4(1), 10-23.

Bowdin, G.A.J., Allen, J., O’Toole, W., Harris, R., \& McDonnell, I. (2011). Events management (3rd ed.). New York: Butterworth-Heinemann.

Brakke, M. (2005). International tourism, demand and GDP implication: A background and empirical analysis. Undergraduate Economic Review, 1(1), 1-38.

Brink, A., \& Berndt, A. (2008). Relationship marketing and customer relationship management. Lansdowne: Juta \& Co Ltd.

Brown, S.A. (2001). Communication in the design process (1st ed.). London: Taylor \& Francis.

Brownell, J. (2008). Leading on land and sea: Competencies and context. International Journal of Hospitality Management, 27, 137-150. https://doi.org/10.1016/j. ijhm.2007.11.003

Burgess, C. (2007). Is there a future for hotel financial controllers? Hospitality Management, 26(1), 161-174. https://doi.org/10.1016/j.ijhm.2005.10.004

Cant, M., Gerber-nel, C., Nel, D., \& Kotze, T. (2008). Marketing research. Pretoria: Van Schaik.

Cant, M.C., \& Van Heerden, C.H. (2008). Personal selling. Lansdowne: Juta and Co Ltd.

Cecil, A., \& Krohn, B. (2012). The process of developing a competency-based academic curriculum in tourism management. Journal of Teaching in Travel \& Tourism, 12(2), 129-145. https://doi.org/10.1080/15313220.2011.624417

Chathoth, P.K., Ungson, G.R., Altinay, L., Chan, E.S.W., Harrington, R., \& Okumus, F. (2014). Barriers affecting organisational adoption of higher order custome engagement in tourism service interactions. Tourism Management, 42, 181-193. https://doi.org/10.1016/j.tourman.2013.12.002

Connolly, P., \& Mcging, G. (2006). Graduate education and hospitality management in Ireland. International Journal of Contemporary Hospitality Management, 18(1), 50-59. https://doi.org/10.1108/09596110610641975

Cronje, G.J.E.J., Du Toit, G.S., Motlatla, M.D.C., \& Marais, A.D.E.K. (2006). Introduction to business management. Cape Town: Oxford.

Davies, D., Taylor, R., \& Savery, L. (2001). The role of appraisal, remuneration and training in improving staff relations in the Western Australian accommodation industry: A comparative study. Journal of European Industrial Training, 25(1), 366-373. https://doi.org/10.1108/EUM0000000005837

Dhar, R.L. (2015). Service quality and the training of employees: The mediating role of organizational commitment. Tourism Management, 46, 419-430. https://doi. org/10.1016/j.tourman.2014.08.001

Ewan, M. (2012). Research area: Tera-scale. Retrieved February 12, 2014, from http:// techresearch.intel.com/articles/Tera-scale/1421

Ewing, E.M. (2007). Changing with the times: Leveraging the web to enhance your employee communications program. Public Relations Tactics, 1(1), 1-13.

Forsyth, P., \& Dwyer, L. (2009). The travel and tourism competitiveness report 2009. Retrieved July 11, 2012, from http://www.weforum.org/pdf/ttcr09/Chapter $\% 20$ 1.6.pdf

George, R. (2013). Marketing tourism in South Africa (4th ed.). Cape Town: Oxford University Press.

George, R.T., \& Hancer, M. (2008). Housekeeping managers and the administration of housekeeping service. International Journal of Hospitality and Tourism Administration, 9(4), 365-383. https://doi.org/10.1080/15256480802427313

Getz, D. (2008). Event tourism: Definition, evolution and research. Tourism Management, 29(1), 403-428. https://doi.org/10.1016/j.tourman.2007.07.017
Hamilton, J.M. (2004). Climate and the destination choice of German tourists. Nota Di Lavoro, 21(1), 1-21. https://doi.org/10.2139/ssrn.504362

Harrington, R.J., \& Ottenbacher, M.C. (2010). Strategic management: An analysis of its representation and focus in recent hospitality research. International Journa of Contemporary Hospitality Management, 23(4), 439-462. https://doi.org/ 10.1108/09596111111129977

Hartman, R. (2011). Leaders of the hospitality industry. In K. Bowers (Ed.), Da Vinci's Vault (pp. 68-76). Denver: Johnsons \& Wales University.

Haynes, P., \& Fryer, G. (2000). Human resources, service quality and performance: A case study. International Journal of Contemporary Hospitality Management, 12(4), 240-248. https://doi.org/10.1108/09596110010330813

Horng, J.S., Tsal, C.Y., Yang, T.C., Lui, C.H., \& Hu, H.D. (2016). Exploring relationship between proactive personality, work environment and employee creativity among tourism and hospitality employees. International Journal of Hospitality Management, 54, 25-34.

Hough, J., \& White, M. (2001). Using stories to create change: The object lessons of Fredrick Taylor's pig tale. Journal of Management, 27(1), 585-601.

Hudson, S., \& Gilbert, D. (2006). The internet and small hospitality businesses: B\&B marketing in Canada. Journal of Hospitality and Leisure Marketing, 14(1), 99-116. https://doi.org/10.1300/J150v14n01_06

Huebsch, J.C. (1986). Communication (2000). Durban: Butterworths.

Hurd, A., Barcekona, R.J., \& Meldrum, T. (2008). Leisure services management. Champaign, IL: Human Kinethics.

Jeou-shyan, H., Hsuan, H., Chih-hsing, L., Lin, L., \& Chang-yen, T. (2011). Competency analysis of top managers in the Taiwanese hotel industry. International Journal of Hospitality Management, 30(1), 1044-1054. https://doi.org/10.1016/j.ijhm. 2011.03.012

Johanson, M., Ghiselli, R., Shea, L.J., \& Roberts, C. (2010). Revealing key competencies of hospitality graduates demand in industry: A 25 year review. International CHRIE Conference Refereed Track, 5(1), 1-10.

Kandampully, J. (2000). The impact of demand fluctuation on the quality of service: A tourism industry example. Managing Service Quality, 10(1), 10-19. https://doi. org/10.1108/09604520010307012

Kay, C., \& Russette, J. (2000). Hospitality-management competencies: Identifying Managers essential skills. Cornell Hotel and Restaurant Administration Quarterly, 41(1), 52-63. https://doi.org/10.1177/001088040004100217

Killen, C.P., Jugdev, K., Drouin, N., \& Petit, Y. (2011). Advancing project and portfolio management research: Applying strategic management theories. International Journal of Project Management, 30(1), 525-538.

Koens, K., \& Thomas, R. (2015). Is small beautiful? Understanding the contribution of small businesses in township tourism to economic development. Development South Africa, 1, 1-22. https://doi.org/10.1080/0376835X.2015.1010715

Kotler, P., Bowen, J.T., \& Makens, J.C. (2006). Marketing for hospitality and tourism (4th ed.). New Jersey: Pearson Education.

Krejcie, R.V., \& Morgan, D.W. (1970). Determining sample size for research activities. Education and Psychological Measurement, 30(1), 607-610. https://doi. org/10.1177/001316447003000308

Kusluvan, S., Kusluvan, Z., lihan, I., \& Buyruk, L. (2010). The human dimension: A review of human resources management issues in the tourism and hospitality industry. Cornell Hospitality Quarterly, 51(2), 171-214. https://doi.org/10.1177/ 1938965510362871

Lamminmaki, D. (2008). Accounting and the management of outsourcing: An empirical study in the hotel industry. Management Accounting Research, 19(1), 163-181. https://doi.org/10.1016/j.mar.2008.02.002

Leiper, N. (2004). Tourism management (3rd ed.). Sidney, BC: Pearson Hospitality Press.

Leung, R., \& Law, R. (2010). A review of personality research in the tourism and hospitality context. Journal of Travel and Tourism Marketing, 27(5), 439-459. https://doi.org/10.1080/10548408.2010.499058

Lillicrap, D., \& Cousins, J. (2006). Food and beverage service (7th ed.). London: Hodder Arnold.

Louw, R. (2011). Forecasting tourism demand for South Africa. Unpublished master's thesis, North-West University, Potchefstroom.

Lovelock, C., \& Wirtz, J. (2011). Services marketing: People, technology, strategy (7th ed.). London: Pearson Education Limited.

Lovemore, F.C.H., \& Brummer, L.M. (2010). The ABC of financial management: An introduction to financial management and analysis (2nd ed.). Pretoria: Van Schaik.

Lubbe, B. (2005). Tourism management in Southern Africa (2nd ed.). Cape Town: Person Education.

Maharaj, S., \& Balkaran, R. (2014). A comparative analysis of the South African and Global Tourism Competitiveness models. Journal of Economics and Behavioral Studies, 6(4), 273-278.

Mason, R.B. (2007). The external environment's effect on management and strategy. Management Decision, 45, 10-28. https://doi.org/10.1108/00251740710718935

Matjila, J. (2008). An analysis of technology support services for small and medium sized enterprises in selected industrial parks of Pretoria. Unpublished MBA mini dissertation, North-West University, Potchefstroom.

Mayaka, M., \& Akama, J.S. (2007). Systems approach to tourism training and education: The Kenyan case study. Tourism Management, 28(1), 298-306. https:// doi.org/10.1016/j.tourman.2005.12.023 
McManus, G. (2000). The hotel industry. In M.J.S. Jordaan (Ed.), Career guide: Tourism in South Africa (pp. 100-151). Bloemfontein: Tekskor.

Middleton, H. (2002). Complex problem solving in the workplace setting. International Journal of Education Research, 37(1), 67-84. https://doi.org/10.1016/S08830355(02)00022-8

Mmope, P.P. (2010). The role of senior managers at the North-West University in internal communication and employee engagement. Unpublished MAdissertation, North-West University, Potchefstroom.

Nieuwenhuizen, C., \& Rossouw, D. (2012). Business management: A contemporary approach. Claremont: Juta.

Nolen, C., Conway, E., Farrel, T., \& Monks, K. (2010). Competency needs in Irish hotels: Employer and graduate perspectives. Journal of European Industrial Training, 34(5), 432-454. https://doi.org/10.1108/03090591011049800

O'Neill, M.A., Williams, P., Maccarthy, M., \& Groves, R. (2000). Diving into service quality- the dive tour operator perspective. Managing Service Quality, 10(3), 131140. https://doi.org/10.1108/09604520010336650

Page, S.J. (2007). Tourism management for change (2nd ed.). Oxford: ButterworthHeinemann.

Pallant, J. (2010). SPSS survival manual: A step by step guide to data analysis using SPSS (4th ed.). London: Open University Press.

Patiar, A., \& Mia, L. (2009). Transformational leadership style, market completion and departmental performance: Evidence from luxury hotels in Australia. International Journal of Hospitality Management, 28(1), 254-262. https://doi.org/10.1016/j. ijhm.2008.09.003

Perloff, J.M. (2007). Micro-economics (4th ed.). Boston, MA: Pearson.

Posavec, V. (2008). Nova Spivack on the future of twine and the intelligent web. Retrieved May 21, 2014, from http://www.memebox.com/futureblogger/ show/824

Rajaratnam, S.D., Munikrishnan, U.T., Sharif, S.P., \& Vikneswaran, N. (2014). Service quality and previous experience as a moderator in determining tourists satisfaction with rural tourism destinations in Malaysia: A partial least squares approach. Social and Behavioural Sciences, 144, 203-211. https://doi.org/ 10.1016/j.sbspro.2014.07.288

Richie, B.W. (2005). Chaos, crises and disasters: A strategic approach to crisis management in the tourism industry. Tourism Management, 25(1), 669-683.

Rogerson, C.M. (2004). Transforming the South African tourism industry: The emerging black-owned bed and breakfast economy. GeoJournal, 60, 273-281. https://doi.org/10.1023/B:GEJO.0000034734.81953.47

Saayman, A., \& Saayman, M. (2008). Determinants of inbound tourism to South Africa. Tourism Economics, 14(1), 81-96. https://doi.org/10.5367/000000008 783554893

Saayman, M. (2009a). En route with tourism: An introduction text (4th ed.). Cape Town: Juta \& Company Ltd.

Saayman, M. (2009b). Hospitality, leisure \& tourism management (2nd ed.) Potchefstroom: Leisure Publications.

Saayman, M., \& Geldenhuys, S. (2003). An analysis of skills required for selected sectors of the tourism industry. SA Journal for Research in Sport, Physical Education and Recreation, 25(1), 83-95.

Sewdass, N., \& Du Toit, A. (2014). Current state of competitiveness intelligence in South Africa. International Journal of Information Management, 34, 185-190. https://doi.org/10.1016/j.ijinfomgt.2013.10.006
Shaw, G.K. (2010). A risk management model for the tourism industry in South Africa. Unpublished doctoral thesis, North-West University, Potchefstroom.

Sisson, L.G., \& Adams, A.R. (2013). Essential hospitality management competencies: The importance of soft skills. Journal of Hospitality \& Tourism Education, 25, 131145. https://doi.org/10.1080/10963758.2013.826975

Slabbert, E., \& Saayman, M. (2003). Guesthouse management in South Africa (2nd ed.). Potchefstroom: Institute for Tourism and Leisure Studies.

Spowart, J. (2011). Hospitality students' competencies: Are they work ready? Journa of Human Resources in Hospitality \& Tourism, 10, 169-181. https://doi.org/10.10 80/15332845.2011.536940

Stamboulis, Y., \& Skayannis, P. (2003). Innovation strategies and technology for experience-based tourism. Tourism Management, 24(1), 35-43. https://doi. org/10.1016/S0261-5177(02)00047-X

Statistics South Africa. 2009. Key findings, quarterly labour force survey. Retrieved March 17, 2013 from http://www.statssa.gov.za/publications/statsdownload. asp?PPN=P0211\&SCH $=4503$

Sternberg, R.J., \& Zhang, L.F., (2000). Perspectives on cognitive, learning and thinking styles. Orlando, FL: Lawrence Erlbaum Associates.

Suh, E., West, J.J., \& Shin, J. (2012). Important competency requirements for managers in the hospitality industry. Journal of Hospitality, Leisure, Sport and Tourism Education, 11, 101-112. https://doi.org/10.1016/j.jhlste.2012.02.005

Sun, M., \& Howard, R. (2004). Understanding I.T. in construction. London: Spon.

Swanson, R.A., \& Holton, E.F. (2009). Foundations of human resource development (2nd ed.). San Francisco, CA: Berrett-Koehler.

Tassiopoulos, D. (2010). Events management: A developmental and managerial approach (3rd ed.). Claremont, CA: Juta.

Tassiopoulos, D. (2011). New tourism ventures (2nd ed.). Claremont, CA: Juta.

Tassiopoulos, D. (2014). Small, micro and medium tourism enterprises in South Africa: Profiling the decision-makers. Proceedings of the Academy of Entrepreneurship 20(2), 1-8.

TGCSA. (2013). About the TGCSA. Retrieved April 21, 2013, from http://www. tourismgrading.co.za/

Thekiso, T.A. (2011). Management performance measurement business schoo educated managers in the North-West and Vaal Triangle areas. Unpublished MBA dissertation, North-West University, Potchefstroom.

Theunissen, P., \& Wan Noordin, W.N. (2012). Revisiting the concept 'dialogue' in public relations. Public Relations Review, 38(1), 5-13. https://doi.org/10.1016/j. pubrev.2011.09.006

Tsaur, S., \& Lin, Y. (2003). Promoting service quality in tourist hotels: The role of HRM practices and service behaviour. Tourism Management, 24(1), 471-481.

Weiermair, K. (2000). Tourists' perceptions towards and satisfaction with service quality in the cross-cultural service encounter: Implications for hospitality and tourism management. Managing Service Quality, 10(6), 397-409. https://doi. org/10.1108/09604520010351220

World Travel \& Tourism Council (WTTC). (2014). Travel and tourism economic impact. London: WTTC.

Zehrer, A., \& Mössenlechner, C. (2009). Key competencies of tourism graduates: The employers' point of view. Journal of Teaching in Travel \& Tourism, 9(3-4), 266287. https://doi.org/10.1080/15313220903445215 